\title{
The Federal Loyalty-Security Program: A Proposed Statute ${ }^{\dagger}$
}

\author{
Frank $F$. Mankiewicz,* \\ John K. Mangum** and Graham B. Moody, Jr.*:**
}

Few political issues occupying the attention of the American people for the postwar decade have generated so much controversy as the attempts by the United States Government, in the face of an international Communist conspiracy, to strike a balance in public employment between the needs of internal security and the preservation of traditional individual liberties. ${ }^{1}$ Considerable criticism has been levelled against both the particulars ${ }^{2}$ and the whole concept of a program to ensure security in government employment. ${ }^{3}$ But surprisingly few reform measures have been proposed by the critics of the program.

In the belief that whatever the political merit or social desirability ${ }^{4}$ of a program designed to guarantee that "security risks" are not occupying

$\dagger$ The writers wish to acknowledge their thanks for the generous assistance and advice of Professor Frank C. Newman, School of Law, University of California, Berkeley, in whose seminar on Legislation much of this statute was written. Thanks are also due to Mrs. Ellen A. Peters, Associate in Law, 1955-56, who assisted in the editing of the material for publication.

* Member, California Bar.

** Member, Utah Bar.

*** Head Law Clerk to the Chief Justice of the United States, October Term, 1955. Mr. Moody's contribution to this article was made while he was a student at the School of Law, University of California, Berkeley.

I See, e.g., Tomprins, Loyalty-Security Programs for Federar EMrployees (1955); Arnold, The Case Against the Federal Loyalty Progran, passim (1949); Biddle, Sickness of Fear: The Larger Meaning of Loyalty Investigations and Their Impact on Traditional Free Thought, 7 Bull. Aroscr Scr. 323 (1951); Brown and Fassett, Security Tests for Maritime Workers: Dute Process Under the Port Security Program, 62 Yale L.J. 1163 (1953); Emerson and Helfeld, Loyalty Among Government Employees, 58 YALE L.J. 1, 412 (1948); Hoover, Loyalty Among Government Employees-A Comment, 58 Yace L.J. 401,422 (1948) ; Hoover, Role of the FBI in the Federal Employee Security Program, 49 Nw. U. L. REv. 333 (1949); Jahoda and Cook, Security Measures and Freedom of Thought, 61 Yare L.J. 295 (1952); Kaplan, Loyalty Review of Federal Employees, 23 N.Y. U.L. Rev. 437 (1948); Krasilovsky, Elevating the Role of the Informer: The Value of Secret Information, 40 A.B.A.J. 603 (1954); Richardson, The Federal Employee Loyalty Program, 51 CoLum. L. Rev. 546 (1951).

For an excellent summary of the history of the federal loyalty-security program up to 1953, see Bontecou, The Federal Loyadty Security Program (1953); for a comprehensive survey of all presently operating security programs, including those applicable to defense contractors and members of the armed services, and the port security program, see WETNSTEnv, Personnex Security Programs of the Federal Governanent (1954).

2 The programs are variously termed "loyalty programs," "security programs," or combinations of the two. For the purposes of this article the whole complex of regulations and Executive Orders regarding federal employment will be referred to as the "Federal Security Program."

3 See, e.g., Cain, Are You a Security Risk?, See Magazine, Sept. 1955, p. 3 ; TAyLor, GrAND Inquest (1955) ; Barta, GovernMent bX INvestigation (1955). But cf. Hays, Congress Right to Investigate: Two Books Examined, 20 CoMarentary 440 (1955).

4 For what it may be worth, it is the writers' behef that some type of federal security program is both politically and socially justifiable. 
government jobs, some such program will be with us for the foreseeable future, the statute set forth below has been drafted.

We do not claim to have all of the answers, or even to have most of them. Lacking actual experience with security problems, we do not expect this draft statute to be enacted into law. But the paucity of affirmative alternatives offered for the present system has led us to believe that considerable good might come from a wide discussion and appraisal of our proposal.

In assessing the over-all problem of establishing a security system designed to meet the known threat of Communist subversion and yet preserve essential civil liberties, ${ }^{5}$ we are less concerned with procedures than with standards. For example, an employee charged with being a security risk $^{6}$ because of close association with his parents ${ }^{7}$ or brothers, ${ }^{8}$ who have had previous "security" problems of their own, will hardly be helped by the resources of due process. If the charge is true-if he has associated closely with his parents, or with his brothers-cui bono due process? It will do a suspended employee little good to be given the right, for example, to confront witnesses, subpoena evidence, or take a full appeal, if the act which he is charged with committing is one which he did in fact commit, and his commission of the act (for example, "association" with his mother) is a matter of public record. When the charges are of this nature, the proceedings take on an almost nightmarish quality. ${ }^{\circ}$ But while our main concern has been with substantive standards by which federal employees are to be judged, we have also endeavored to set forth improved procedures. ${ }^{10}$

Furthermore, the statute places the administration of the security program under a single government agency. This agency, among its other functions, is responsible for making rules concerning the relevancy of various security charges. One of the important features of the proposed statute

5 Insightful discussions of the difficulties involved in striking this delicate balance can be found in Cook, Demrocratic Rughts Versus Comorunist Activity (1954), and Goldbloom, Axterican Securtit and Freedont (1954).

${ }^{6}$ See Yarmolinsky, Case Studies in Personnel Security 32 (1955).

7 Id. at $45,48,100$.

8 Id, at 109,301 .

${ }^{8}$ Compare the instruction of the Chief Inspector to the accused in Karka, THE TrIaI 17 (1953): "However, if I can't answer your questions, I can at least give you a piece of advice; think less about us and of what is to happen to you, think more about yourself instead. And don't make such an outcry about your feeling innocent, it spoils the not unfavourable impression you make in other respects," with the coinments of Board Members to the accused in a port security case, Yararorinsky, Case Studies in Personnel Secorrty 303 (1955): “. . . in keeping with what Mr. .................... has just said, I think it would be well if you perhaps would do a little more thinking along this line to see just what, and where the source of contamination lies; because it doesn't seem reasonable that all of the members of the family would have been screened, unless there would have been some basis for it, and perhaps in the future for your own benefit you probably would do well to sort of look about a little and see just where this source lies. Even though you are dealing with your own brothers, for your own good, and that would be my recommendation in this particular case."

10 See the proposed statute at $\S \S 6,7$ and 9 infra. 
is that it differentiates, on the basis of ultimate relevancy, among various types of charges which may be made; certain charges are on grounds of policy excluded entirely from any consideration.

\section{Scope of Program}

The Act covers non-military federal employment only. This sharply limits the field. ${ }^{11}$ Certain portions of the statute, such as the sections proscribing the bringing of irrelevant charges, could be modified easily to apply to other areas of security-sensitive employment. In other respects, more detailed changes would be required to adapt the basic structure to the requirements of military security. ${ }^{12}$

Proposed Statute

\section{A BIIL}

For the establishment of a uniform security program for certain employees of the United States, and for the establishment of a Federal Personnel Security Agency, and for other purposes.

\section{Comments}

We have had considerable correspondence with attorneys and others concerned with the operation of the federal security program. Many of their suggestions have been incorporated. Several argued that the security program should not be cast in the form of a statute, but should remain an Execultive Order. However, it is our belief that a statute, although more rigid in form and less easily amended than an Executive Order, is the better answer to the problem.

Throughout, we have used the phrase "endanger the national security" rather than the standard presently imposed by Executive Order 10450, "clearly consistent with the national security." 13
Be it enacted by the Senate and House of Representatives of the United States of American in Congress assembled. That Government service is so essential to the operations of the nation that

11 See Wennstem, Personnel Security Programs of the Federal Governarent (1954) for a description of related security programs in the areas of port security, armed services and defense contractors.

12 Some differentiation must be made in treatment, for example, among draftees and volunteers, as well as regular and reserve officers recalled to active duty, and a policy should be clearly set forth covering the penalties, if any, to be imposed upon servicemen by way of discharge less than lonorable for pre-service political activities, acknowledged or not by the recruit upon entering active duty. See Bernstein v. Herren, 136 F. Supp. 493 (S.D. N.Y. 1955), for a lolding that the Army is constitutionally disabled from imposing any such penalty. The Army seems to have acquiesced in announcing that no less-than-honorable discharges will be given for pre-service political activity. San Francisco Chronicle, Jan. 29, 1956, p. 1.

13 The language is paraphrased fron Executive Order 10450, promulgated April 29, 1953, the basic authority under which security cases now proceed. The standard to which the criteria set forth in Executive Order 10450 are to be applied is that the employment of the individual "must be clearly consistent with the national security," and the national security is defined in regulations issued under Executive Order 10450 to include "the military, economic and productive strength of the United States." 
those engaged in government service are particularly well situated not only to contribute to the welfare of the nation, but also to injure it. Persons whose employment would endanger the national security should not be hired or, if they are already employed, should be removed. But if the procedures for removing those persons become arbitrary or oppressive, the government service will lose that spirit of freedom and independence upon which the proper conduct of public affairs depends. ${ }^{14}$

SEc. 2. (a) There is establislied a Federal Personnel Security Agency, liereafter called the Agency. (For additional defimitions see Section 11.)

(b) The principal office of the Agency shall be in the District of Columbia, but the Agency or any duly authorized representative may exercise any or all of its powers in any place.

(c) Notwithstanding the provisions of any other Act, the Agency shall have the sole authority to determine whether the retention or employment in the federal service of any employee would endanger the national security and shall have such power as is necessary to carry out this authority, including but not restricted to the power to make such regulations consistent with the provisions of this Act as may be necessary for the performance of the functions of the Agency. ${ }^{15}$

(d) The primcipal officer of the Agency shall be a Director, wlo shall be appointed by the President. The Director shall serve for a term of five years and may be reappointed. He may be removed by the President for mefficiency, neglect of duty, or malfeasance in office.
Semantically there may be little difference, but if the determination in issue is whether employment "endangers" rather than "is consistent with" the national security, a sterner view of the criteria, and perhaps of the human values involved, might well result.

At present, the ultimate determination in security matters is made by the head of the department in which the employee works. This has resulted in a multiplicity of standards. Also, if the head of a department is to be held responsible (e.g., by Congressional investigating committees) for each determination as to the security of each employee in his department, is it not likely that political pressures might compel resolution of all doubts, no matter how slight, against the employee, in a way not contemplated by the framers of the program?

14 See the first three introductory paragraphs of Executive Order 10450. Executive Order 10450 is reproduced in full as an appendix to this article. Footnote citations of Executive Order 10450 hereafter will be to APPENDIX.

15 See APRENDIX $\$ \S 2,7$. 
The Director shall receive compensation at the rate of $\$ 20,000$ per annum.

(e) There are established within the Agency the following divisions:

(1) An Evaluation and Research Division, which shall

(i) conduct studies to determine which foreign or domestic organizations, associations, movements, groups, or other combinations of persons are or have been Communist-dominated, Communist-controlled, or Fascist, or advocate or advocated the use of force or violence to overthrow the government of the United States or the alteration of the form of government of the United States by unconstitutional means;

(ii) recommend to the Director the adoption of regulations particularizing the facts of time and place and circumstances which shall make material the matters enumerated in section 5 (b) of this Act; and

(iii) recommend to the Director that proceedings be initiated under section 6 of this Act, if the Division has reason to believe that any employee is a security risk.

In performing its duties the Division shall advise and consult with the intelligence and other investigative agencies of the federal government and shall continuously evaluate information received from such agencies relating to activities of organizations or individuals affecting the national security. ${ }^{16}$

(2) A Risk Classification Division, which shall proinulgate security risk classifications of the employment positions in federal service covered by this Act. The criterion for establishing such classifications shall be the opportunity to endanger national security afforded by particular employment positions. In performing its duties the Division shall advise and consult with the appropriate federal government agencies. ${ }^{17}$
It will become apparent that under section 2(e) the Evaluation and Research Division will be engaged in establishing a "list" of subversive organizations. It is this list which is to form the basis of the determination by the Director under section $5(b)$, infra, that certain charges may be brought. Thus, if the Evaluation and Research Division determines, after study, that the particular branch of $X$ organization located in the city of $Y$ has been Communist-dominated from 1951 until the present time, allegations that an employee was a member of such organization must, to become relevant and meet the criteria of section 5, infra, specify that he was a member of that particular branch at the times indicated. See also Statute at section $9(b)$, infra, and comment pertaining thereto.

10 See APPENDIX $\$ \$ 3(\mathrm{a}), 8(\mathrm{~b}), 8(\mathrm{c}), 8(\mathrm{~d}), 9$.

17 See APpeandI $\$ 3(\mathrm{~b})$.

Here it is contemplated that it is entirely possible that an employee in one job may be a security risk, but that in another job he would not. The Risk Classification Division, after advice and consultation with the appropriate government agencies, will promulgate a master list covering federal employment and indicate thereon which jobs are sensitive, in varying degrees, and which are not. Thus, the determination that 
an employee is a security risk will have to be made upon the basis not only of his own activities and conduct, but also of the job he is performing or seeks to perform. This is the older and, we believe, the better view of security.

(3) A Hearing Division, which shall conduct hearings in accordance with the procedures set forth in section 6 , and which shall be organized with Hearing Boards in appropriate geographical locations. ${ }^{18}$

(4) A Litigation Division, which shall represent the Agency. ${ }^{19}$

(5) A Legal Aid Division, which shall represent, at his request, any employee against whom proceedings are initiated under this Act. ${ }^{20}$

(6) An Administrative Division, which shall provide stenographic, clerical, and other services required by the Agency.

(7) A Review Board, which shall review decisions of the Hearing Boards as prescribed in section 6 of this Act. ${ }^{21}$

SEc. 3. No einployee shall be dismissed from or denied employment in the federal service on the ground in whole or in part that he is a security risk unless it is affirmatively found that his retention or employment endangers the national security. ${ }^{22}$

SEC. 4. In determining whether a person's retention or employment in the federal service endangers the national

The studies made so far of the operation of the present security program indicate that many accused employees find themselves without the means to retain adequate legal counsel.

No such exclusiveness is provided by Executive Order 10450, which lists criteria to apply to the standard set forth

18 Compare similar provisions in one of the more recent and more detailed administrative regulations issued pursuant to Executive Order 10450 by the Department of the Air Force under its Civilian Personnel Security Program, 32 C.F.R. §§ 889.3, 889.4 (1954).

10 Ibid.

20 This provision has no counterpart in any of the existing security programs.

21 Compare 32 C.F.R. $\$ \$ 889.3,889.4$ (1954).

22 See APPENDIX \$ 5 . 
security, only the criteria enumerated in this section shall be considered.

- The activities, associations and other items included in the criteria are of varying degrees of seriousness. Therefore, the ultimate determination whether an employee is a security risk should be an over-all common-sense one, based on all available information. The criteria to be considered are as follows:

(a) The opportunity afforded by the particular employment position to endanger the national security. ${ }^{25}$

(b) Facts which furnish reason to believe that the individual is subject to coercion, influence, or pressure which may cause him to act contrary to the national security. ${ }^{26}$ but does not require that only those criteria be considered. ${ }^{23}$

A similar provision is included in the security regulations promulgated by the Secretary of Defense to apply to civilian employees of the military establishment. ${ }^{24}$ This is an application of the "whole man" theory of security evaluation under which a particular item, possibly damaging in itself, must be weighed against other relevant information.

Here is an example of the "balanced risk" theory. One factor to be considered in security risk determinations is the nature of the job. The same verified information about an individual wlich might justify his exclusion from certain positions in the Atomic Energy Commission, or from a policy-making job in the Department of State, might well be insufficient to justify his discharge from a menial position in a post office. The determination referred to in this subsection will be made by the Risk Classification Division.

Executive Order 10450 section 8(a) (1) lists among its criteria "... (iii) any criminal, infamous, dishonest, immoral, or notoriously disgraceful conduct, habitual use of intoxicants to excess, drug addiction, or sexual perversion," and (v) of section 8(a)(1) uses language largely similar to ours. We have confined all "extra-political" activities to this subsection, because we believe that the only possible connection between the kind of activity referred to in the above subsections of Executive Order 10450 and an employee's status as a security risk is the possibility that such activity may make him more susceptible to blackmail, coercion, etc.

23 See APPENDIX \$ 8(a), introductory paragraph: "Such information shall relate, but shall not be limited, to the following ....." (Emphasis added.)

24 See, e.g., regulations covering civilian employees of the Air Force, 32 C.F.R. $\$ 889.6$ (c) (1954).

25 Compare id. \& 889.1(d).

26 See APPENDIX $\$ 8(a)$ (1). 
(c) Commission of any act of sabotage, espionage, treason, or sedition, or attempts thereat or preparation therefor; or conspiring with, or aiding or abetting, another to commit or attempt to commit any act of sabotage, espionage, treason, or sedition. ${ }^{27}$

(d) Establishing or continuing a close association with a person known to the employee to be a saboteur, spy, traitor, seditionist, anarchist, or revolutionist, or an espionage or other secret agent of a foreign nation, or any person who advocates the use of force or violence to overthrow the government of the United States or to alter the form of government of the United States by unconstitutional means. ${ }^{29}$

(e) Advocacy of the use of force or violence to overthrow the government of the United States, or of the alteration of the form of government of the United States by unconstitutional means. ${ }^{30}$

(f) Taking membership in or affiliating or closely associating with any foreign or domestic organization, association, movement, group, or other combination of persons which, at any time during such membership or affiliation or close association, is found by the Agency and known to the employee to have been Communist-dominated, Communist-controlled, or Fascist, or to have advocated the use of force or violence to overthrow the government of the United States by unconstitutional means. ${ }^{31}$

(g) Intentional or negligent unauthorized disclosure to any person of classified infornation, or of other information the disclosure of which is prohibited by law, or intentional or negli-
Section 8(a)(3) of Executive Order 10450 is changed by this subsection to include the requirement that the saboteur, spy, secret agent, etc., be a person knoren to the employee to be such. ${ }^{28}$
The significance of the change from section $8(a)(5)$ of Executive Order 10450 made in this subsection is the same as that described in the comment upon section $4(d)$, supra.

\footnotetext{
27 See Appendix \$ 8(a) (2).

28 Cf. Weiman v. Updegraff, 344 U.S. 183 (1952).

29 See APPENDIX \& 8(a) (3).

30 See APPENDIX $\$ 8(a)(4)$.

31 See APPENDIX \& 9(a) (5).
} 
gent violation or disregard of security regulations. ${ }^{32}$

(h) Refusal upon the ground of constitutional privilege against self-incrimination to give testimony before a congressional or state legislative committee or any grand jury concerning any of the acts or activities identified in subdivisions (c) through (g) of this section, or refusal upon the same ground to answer any question at any time during the Agency hearing. ${ }^{34}$

SEc. 5. (a) The written notice required by section $6(\mathrm{~b})$ of this Act shall not include or be amended to include any allegation that the einployee merely

(1) signed any petition;

(2) purchased, subscribed to, received, or read any publication;

(3) associated with any person if the association is or was limited to

(i) membership in the same military unit,

(ii) membership in the same trade, professional, religious, or fraternal organization, borhood,

(iii) residence in the same neigh-

(iv) attendance at the same social functions,

(v) attendance at the same educational institution;

(4) was present at a gathering of two or more people;

(5) exhibited unusual tastes in matters of recreation and culture; 35

(6) traveled outside the territorial limits of the United States;
It should be borne in mind that criteria (a) through (h) of this section are exclusive ${ }^{33}$ in that no others may be used in applying the standard set in section 3, and that they are criteria not for automatic dismissal as a security risk, but merely for initiating procedures which may possibly lead to such a dismissal.

It is our belief that sections $5(a)$ and (b) constitute the heart of the proposed statute. Subsections (1) through (11) of section $5(a)$ list allegations which may not be used to set disqualification procedures in motion. These specified allegations may not be used alone. They are at all times irrelevant as a basis for preferring a charge, may never be used as a basis for determining that a person is a security risk, would only be relevant if inextricably linked somehow with a permissible allegation, and even then could have no independent relevance. Thus, the fact that a person visited the Soviet Union in 1936 would be irrelevant except as such fact might be relevant to his having received espionage training while there. The fact of such visit would attain relevancy only in connection with an allegation based upon sections $4(c)$ or $4(d)$. Similarly, the fact that an employee signed any petition, or served in the same military unit with anyone, provided the association was so limited, or registered to vote

32 See APPENDTX $\& 8(a)(6)$.

33 See APPENDIX \& 8(a) (7) for one of the explicit criteria of Executive Order 10450 not incorporated into the proposed set of criteria.

34 See APPENDIX \& 8(a) (8).

35 Consider the deportation proceeding referred to in the American Civil Liberties Union News, San Francisco, October 1954, p. 1. The witness against the alien testified that the alien professed a preference for European soccer as against American football, that he did not believe in refrigerators, that his favorite dish was beef stroganoff, and that he and his wife celebrated Russian Easter and preferred it to Christmas, to which the examiner asked the witness whether le did not think the alien meant that Communist Easter was much better than Christmas, to which the witness rephed that he did. 
(7) registered to vote under the laws of any state or territory as a member of any political party;

(8) voted in any election for any candidate for public office;

(9) used an alias;

(10) performed an ordinary function as a participant in any state or federal adjudication;

(11) expressed any opinion on any public matter, except advocacy of use of force or violence to overthrow the government of the United States by unconstitutional means.

(b) Unless the Director has by regulation determined with reasonable particularity the facts of time and place and circumstance which shall make the following matters material to a determination whether an employee is a security risk, the written notice required by section $6(\mathrm{~b})$ of this Act shall not include any allegation that the employee merely

(1) solicited the signatures of others to any petition;

(2) solicited others to purchase, subscribe to, or read any publication; who

(3) associated witl any person

(i) is or was his spouse,

(ii) is or was his employer, employee, co-worker, or business associate,

(iii) is or was a member of his family by blood or marriage withm the third degree of consanguinity,

(iv) gave his name as a reference or whose name he used as a reference,

(v) appears or appeared by name in any of the employee's compilations of addresses, telephone numbers, or similar memoranda, diaries or correspondence, or who similarly used the employee's name or corresponded with the employee, or with whom the employee corresponded; tion; at any time as a member of any political party, may be admissible as evidence tending to prove another charge, but may never be included either as an allegation standing alone or as the basis for decision. To sum up the import of this section, none of these acts may be made the basis, in whole or in part, for preferring an initial charge or determining that an employee is a security risk.

This section qualifies the absolute prohibition of section 5(a). Whereas the acts described in section 5(a) may not in any event form the basis for a charge that an employee is a security risk, the acts set forth in section $5(b)$ may form the basis for such a charge, but only if regulations have validly issued describing with particularity the facts of time and place and circumstances which make them material. [See statute at section 9, infra.] Thus, while the signing of any petition may not form the basis of a charge, the solicitation of signatures to certain petitions may. The regulation in this case would provide, after the survey and study conducted by the Evaluation and Research Division, that the solicitation of signatures to the petitions described by said named organizations at designated times for specific purposes could form the basis for a charge. To put this in its clearest light, the fact that an employee signed the Stockholm Peace Petition could not form the basis of a charge; the fact that he circulated the Stockholm Peace Petition and solicited signatures for it could. It will be observed that the distinctions between sections $5(a)$ and $5(b)$ are generally the distinctions between membership and leadership, between passivity and activity; in short, between conduct which might very possibly be innocent and which, in 
(5) was an officer of, or served on a committee or staff of, any organization;

(6) contributed money, or services, or any other thing of value to any organization;

(7) solicited from others the contribution to any organization of money, or services, or any other thing of value;

(8) permitted the use of his name by any organization in such a manner as to indicate his sponsorship or approval of the organization;

(9) contributed money, or services, or any other thing of value to any political party or for the purpose of supporting the candidacy of any person for public office;

(10) solicited from others the contribution of money, or services, or any other thing of value to any political party or for the purpose of supporting the candidacy of any person for public office;

(11) was an officer of any political party;

(12) gave or received business or professional custom or patronage to or from any person;

(13) lived in a particular neighborhood. ${ }^{36}$

SEc. 6. (a) If the Agency has reason to believe that an employee's retention or employment in his position endangers the national security, it may recommend to the employing department or agency that such employee's employment be suspended until it has been finally determined whether or not the employee is a security risk. Any employee whose employment is so suspended shall continue to receive compensation at the same rate he was receiving at the date of suspension, but not to exceed the difference between the amount which he would normally have any event, should be protected from inquiry, and conduct which, while possibly innocent, requires explanation.
Two weaknesses of the present system are proposed to be remedied. By this section the Agency, even if it has reason to believe that an employee's retention endangers the national security, need not recommend the employee's suspension until the matter has been finally determined, although it may do so earlier. We have made provision for interim pay for suspended employees in the belief that suspension without pay for the entire period of investigation, hearing and final determination is one of the major hardships caused employees by the present program. ${ }^{37}$

36 This section has no counterpart in any of the existing security regulations.

37 See Yarmoltnstry, Case Studies In Personnel Security, passim (1955). 
earned during such period and his interim net earnings, if any. ${ }^{38}$

(b) Within five days after it has been recommended that an employee be suspended the employee shall be given a written notice which shall include

(1) specific allegations of the reasons why his retention or employment in federal service is believed to endanger the national security,

(2) a statement advising him that he is entitled to the advice and representation of counsel at every stage of the proceeding, and further advising him that he may request the assistance of counsel to be assigned by the Legal Aid Division, and

(3) a statement of the time limits prescribed in this section for the doing of various acts. ${ }^{39}$

(c) Within thirty days after receipt of the written notice prescribed in subdivision (b) of this section the employee may file with the Agency such statements and affidavits as he desires to show that his retention or employment in his position does not endanger the national security. Upon request of the employee the Agency may, in its discretion, extend the time allowed the employee to file statements and affidavits as provided in this subdivision and grant a continuance of the hearing. ${ }^{40}$

(d) Within twenty days after receipt of the employee's statements and affidavits filed as provided in subdivision (c) of this section, the Agency shall either order the employee's reinstatement or set a date for a hearing. The employee shall be immediately notified by registered mail of the date set for his hearing, which shall not be held less than thirty nor more than sixty days after the mailing of such notice, unless a continuance is granted under subdivision (1) of this section. ${ }^{41}$

38 See APpendix $\$ 6$.

39 Compare 32 C.F.R. $\$ \S 889.14$ (d) and (e) (1954).

40 Compare id. $\$ 889.14$ (d) (1954).

41 Compare id. $\$ \S 889.15$ (a) and (b) (1954). 
(e) The Agency shall formulate its own rules of procedure consistent with generally accepted standards of due process. The Hearing Boards shall not consider any evidence the source and content of which are not made available to the employee or which is not relevant to any material issue raised in the proceedings, provided, however, that upon affidavit of the Attorney General that such disclosure in any particular adjudication would jeopardize the intelligence or espionage system of the United States, such disclosure need not be made. The employee shall not be asked whether he believes he has had a fair hearing or questions of similar import. The employee shall have the right to cross-examine the witnesses who appear against him. The record of the hearing shall include all testimony and other evidence received, the written notice required by section 6(b) of this Act, and the findings of the Hearing Board. The employee shall be furnished a copy of the record at no cost to him. ${ }^{43}$

(f) (1) In the course of the hearing, no employee shall be excused from testifying or from producing books, papers or other evidence, on the ground that the testimony or evidence required of him may tend to incriminate him or subject him to a penalty or forfeiture; but no such employee shall be prosecuted or subjected to any penalty or forfeiture for or on account of any transaction, matter or thing concerning which he is so compelled, after having claimed his privilege against self-incrimination, to testify or produce evidence, nor shall testimony so compelled be used as evidence in any criminal proceeding against him in any court.

(2) No person shall be exempt under the provision of this section from prosecution for perjury or contempt committed while giving testimony or
This subsection proposes a definite answer to the questions as to confrontation of witnesses raised but left unanswered in Peters v. Hobby. ${ }^{42}$ Only an affidavit of the Attorney General, alleging that the security of the United States would be damaged by the identification and examination of a particular Government witness in a particular case, would avoid the effect of the sub. section.

Available records of security hearings indicate that employees whose security risk status has been put into question are often asked whether they believe they have had a fair hearing. It is our belief that such a question is unfair. In effect, the employee is being asked prior to decision, to praise or condemn the conduct of those who are to exonerate or condemn him. 
producing evidence under compulsion as provided in this section. ${ }^{44}$

(g) The Agency shall have the power, on request or on its own initiative, to subpoena witnesses and documents and make payments for witnesses' fees or travel expenses. ${ }^{45}$

(h) Within thirty days after conclusion of the hearing the Hearing Board shall render a written decision which shall be based on all the evidence and which shall be supported by a statement of reasons. A copy of the decision shall be immediately furnished to the employee. ${ }^{48}$

(i) The decision shall include either

(1) a recommendation to the employing department or agency that the employee be dismissed, or

(2) a recommendation to the employing department or agency that the employee be transferred or given a certificate of eligibility entitling him to employment affording less opportunity to endanger the national security than his present employment, or

(3) an order to the employing agency or department that the employee be reinstated or that he be restored to the status of eligible applicant as the case may be. ${ }^{4 \tau}$

(j) Either the Agency or the employee may file a notice of appeal with the Hearing Board within ten days after receipt of its decision. The notice of appeal shall specify the grounds upon which the appeal is taken. The Hearing Board shall immediately transmit the record and the notice of appeal to the
It will be seen from subsection (1) that the final decision as to the recommended dismissal of an employee found to be a security risk is left to the employing department, on the theory that for good and sufficient reasons it may elect to take a "calculated risk" if it believes that the employee's service is sufficiently valuable when weighed against the possible danger to the national security which that employment might represent. However, if it is found that the employee is not a security risk, no such discretion is left to the employing agency and he must be restored to his previous position. By withdrawing discretionary authority from the employing agency in the case of an employee who has been "cleared," it is believed that the statutory language will remove the not inconsiderable pressure now felt by department heads who might fear a subsequent legislative inquiry.

44 This subsection has no counterpart in any of the existing security regulations.

45 Compare 32 C.F.R. $\$ 889.15$ (c) (1954).

46 Compare id. $\$ \S 889.17$ (a)-(c) (1954).

47 Compare id. $\$ \$ 889.17$ (d), (e) (1954). 
Review Board. Within 30 days after notice of appeal has been filed, the employee and the Litigation Division may file written briefs with the Review Board, and the employee may, on his request, appear personally before the Review Board. Within 30 days after the last day on which written briefs may be filed the Review Board shall render its decision. The employee and the employing department or agency shall be immediately furnished a copy of the decision of the Review Board. ${ }^{48}$

(k) While any appeal from a decision of a Hearing Board or of the Review Board is pending, no action shall be taken upon any recommendation in the Hearing Board's decision. ${ }^{48}$

(1) If anything contained in the record of a proceeding under this Act reflects on its face adversely upon any organization or any person a citizen or resident of, or domiciled within the territorial limits of, the United States of America, such organization or person shall be furnished by registered mail, when a mailing address can be reasonably determined, a copy of that portion of the record in which the adverse reflection appears and a notice that a statement of denial or explanation may be submitted to the Agency and made a part of the record. ${ }^{50}$

(m) No person shall be present at any hearing except authorized Agency representatives, the employee, the employee's counsel, and witnesses. ${ }^{51}$

(n) Without the employee's consent, information elicited in the course of Agency proceedings may not be dis-
The provision for personal appearance has been inserted because of the belief of many of those who have been consulted that the employee is in all events his own "best witness," and that the Review Board can better determine the case if it has an opportunity to hear him and see him, than if it is restricted to the bare bones of the record.

One of the purposes of this subsection in addition to fairness, generally, is to limit the possibility that precedents will be made for future determination about persons, associations, or organizational affiliations charged against an employee. Thus, if it is alleged that an employee was a close associate of $X$ or a member of $Y$ organization, and he is found to be a security risk on the basis of that and other evidence, a subsequent proceeding involving another employee might be determined adversely to the employee on the sole ground of association with $X$ or affiliation with $Y$. By requiring notification of third parties so mentioned, and permitting them to contest the adverse reflection, it is believed that the possibility of this result will be minimized.

\footnotetext{
48 Compare id. $\$ 889.18$ (1954).

49 This subsection has no counterpart in any of the existing security regulations.

50 This subsection has no counterpart in any of the existing security regulations.

51 This subsection has no counterpart in any of the existing security regulations.
} 
closed, except to persons specifically authorized by the Director to receive such information. Disclosure without consent or authorization shall be a crime punishable by a fine not to exceed $\$ 10,000$ or imprisonment for not more than one year, or both. ${ }^{52}$

SEc. 7. (a) No allegation that an employee is a security risk shall be made under this Act if he has been cleared after a hearing under a prior federal loyalty or security program, unless

(1) persuasive and substantial new evidence that he may be a security risk is offered, or

(2) he is promoted or transferred to a position affording greater opportunity to endanger the national security than his former employment and the Agency has reason to beheve that the employee niay be a security risk in his new employment.

(b) Upon application for employunent any employee who was dismissed or denied employment under a prior federal loyalty or security program may request a hearing under this Act. ${ }^{53}$

SEc. 8. This Act shall not apply to agencies designated by the President as primarily engaged in intelligence work. The names of these agencies shall be reported to the Congress by the President and their exemption from the provisions of this Act shall be considered to be approved unless a negative vote of both Houses is taken within 90 days. ${ }^{55}$

SEc. 9. (a) General notice of proposed rulemaking shall be published in the Federal Register and shall include

(1) a statement of the time, place,
Possible constitutional objections have been raised to the use of this procedure. ${ }^{54}$

52 Compare 32 C.F.R. $\$ 889.20$ (1954).

53 See APPENDIX $\$ 11$.

54 Ginnane, The Control of Federal Administration by Congressional Resolutions and Committees, 66 Harv. L. Rev. 569 (1953). But cf. Newman \& Keaton, Congress and the Faithful Execution of Laws-Should Legislators Supervise Administrators?, 41 CALIF. L. REv. 565, 587 (1953).

s5 See APPENDIX $\$ 1$. 
and nature of public rulemaking proceedings;

(2) reference to the authority under which the rule is proposed;

(3) either the terms or substance of the proposed rule or a description of the subject and issues involved.

This subsection shall not apply in any situation in which the Agency for good cause finds (and incorporates the finding and a brief statement of the reasons therefor in the rules issued) that notice and public procedure thereon are inpracticable, unnecessary, or contrary to the national security.

(b) After notice required by this section, the Agency shall afford interested persons an opportunity to participate in the rulemaking through submission of written data, views or arguments with or without opportunity to present the same orally im any manner; and after consideration of all relevant matter presented, the Agency shall incorporate in any rules adopted a concise general statement of their basis and purpose.

(c) The required publication or service of any substantive rule (other than one granting or recoguizing exemption or relieving restriction or interpretative rules and statements of policy) shall be made not less than thirty days prior to the effective date thereof except as otherwise provided by the Agency upon good cause found and pubhished with the rule.

(d) The Agency shall accord any interested person the right to petition for the issuance, amendment, or repeal of a rule. ${ }^{57}$

SEc. 10. Section 5 of the Federal Administrative Procedure Act, 60 Stat. 237 (1946), 5 U.S.C. $\$ 1001$ (1952), shall not be applicable to proceedings under this Act.
It is believed that this procedure will answer some, if not all, of the objections to the compilation and use of the socalled "Attorney General's list" raised by the decision in Anti-Fascist Committee v. McGrath, 50 if indeed any objections were raised by any combination of the decisions of the Justices in that case.

66341 U.S. 123 (1950).

57 This section and all the following sections of the statute have no counterpart in any of the existing security regulations. 
SEc. 11. In this Act, unless the context or subject matter otherwise requires:

(a) "Employee" means any person serving in the federal service and applicants for employment therein. The federal service, for the purpose of this statute, does not include the armed services.

(b) "Dismissed" includes discharge from einployment and removal from lists of eligible applicants.

(c) "Security risk" means an employee whose retention or employment in federal service endangers the national security.

(d) "Suspension" includes temporary removal from employment and from lists of eligible applicants.

SEC. 12. There are hereby authorized to be appropriated to the Agency such sums as may be necessary to carry out its functions.

SEC. 13. If any provision of this Act, or the application thereof to any persons or circumstances, is held invalid, the remainder of this Act, and the application of such provision to other persons or circumstances shall not be affected thereby.

SEc. 14. This Act may be cited as the Federal Personnel Security Act of 195 .....

\section{APPENDIX \\ Executive Order 10450* \\ Security Requirements for Government Employment}

WEEREAS the interests of the national security require that all persons privileged to be employed in the departments and agencies of the Government, shall be reliable, trustworthy, of good conduct and character, and of complete and unswerving loyalty to the United States; and

WHEREAS the American tradition that all persons should receive fair, impartial, and equitable treatment at the hands of the Government requires that all persons seeking the privilege of employment or privileged to be employed in the departments and agencies of the Government be adjudged by mutually consistent and no less than minimum standards and procedures among the departments and agencies governing the employment and retention in employment of persons in the Federal service:

* 3 C.F.R., 1953 Supp., p. 72. The text of the Appendix incorporates amendments to Exec. Order No. 10450 appearing in the following supplements to Title 3 of the Code of Federal Regulations: 1953 Supp., p. 109 (Exec. Order No. 10491) ; 1954 Supp., p. 59 (Exec. Order No. 10531); 1954 Supp., p. 66 (Exec. Order No. 10550). 
NOw, THEREFORE, by virtue of the authority vested in me by the Constitution and statutes of the United States, including section 1753 of the Revised Statutes of the United States (5 U.S.C. 631) ; the Civil Service Act of 1883 (22 Stat. 403; 5 U.S.C. 632, et seq.) ; section 9A of the act of August 2, 1939, 53 Stat. 1148 (5 U.S.C. 118j); and the act of August 26, 1950, 64 Stat. 476 (5 U.S.C. 22-1, et seq.), and as President of the United States, and deeming such action necessary in the best interests of the national security, it is hereby ordered as follows:

Section 1. In addition to the departments and agencies specified in the said act of Aug ust 26,1950, and Executive Order No. $10237^{1}$ of April 26, 1951, the provisions of that act shall apply to all other departments and agencies of the Government.

SEc. 2. The head of each department and agency of the Government shall be responsible for establishing and maintaining within his department or agency an effective program to insure that the employment and retention in employment of any civilian officer or employee within the department or agency is clearly consistent with the interests of the national security.

SEc. 3. (a) The appointinent of each civilian officer or employee in any department or agency of the Government shall be made subject to investigation. The scope of the investigation shall be determined in the first instance according to the degree of adverse effect the occupant of the position sought to be filled could bring about, by virtue of the nature of the position, on the national security, but in no event shall the investigation include less than a national agency check (including a check of the fingerprint files of the Federal Bureau of Investigation), and written inquiries to appropriate local law-enforcement agencies, former employers and supervisors, references, and schools attended by the person under investigation: Provided, that upon request of the head of the department or agency concerned, the Civil Service Commission may, in its discretion, authorize such less investigation as may meet the requirements of the national security with respect to per-diem intermittent, temporary, or seasonal employees, or aliens employed outside the United States. Should there develop at any stage of investigation information indicating that the employment of any such person may not be clearly consistent with the interests of the national security, there shall be conducted with respect to such person a full field investigation, or such less investigation as shall be sufficient to enable the head of the department or agency concerned to determine whether retention of such person is clearly consistent with the interests of the national security.

(b) The head of any department or agency shall designate, or cause to be designated, any position within his department or agency the occupant of which could bring about, by virtue of the nature of the position, a material adverse effect on the national security as a sensitive position. Any position so designated shall be filled or occupied only by a person with respect to whom a full field investigation has been conducted: Provided, that a person occupying a sensitive position at the time it is designated as such may continue to occupy such position pending the completion of a full field investigation, subject to the other provisions of this order: And provided further, that in case of emergency a sensitive position may be filled for a limited period by a person with respect to whom a full field preappointment imvestigation has not been completed if the head of the department or agency concerned finds that such action is necessary in the national interest, which finding shall be made a part of the records of such department or agency.

SEc. 4. The head of each department and agency shall review, or cause to be reviewed, the cases of all civilian officers and employees with respect to whom there has been conducted a full field investigation under Executive Order No. $9835^{2}$ of March 21, 1947, and, after such further investigation as may be appropriate, shall 're-adjudicate, or cause to be re-adjudicatcd, in accordance with the said act of August 26, 1950, such of those cases as have not been adjudicated under a security standard commensurate with that established under this order.

SEC. 5. Whenever there is developed or received by any department or agency information indicating that the retention in employment of any officer or employee of the Government may not be clearly consistent with the interests of the national security, such information shall be forwarded to the head of the employing department or agency or his representative, who, after such investigation as may be appropriate, shall review, or cause to be reviewed, and, where necessary, re-adjudicate, or cause to be re-adjudicated, in accordance with the said act of August 26,1950 , the case of such officer or employee.

SEc. 6. Should there develop at any stage of investigation inforination indicating that the employment of any officer or employee of the Government may not be clearly consistent with

13 C.F.R., 1951 Supp., p. 430.

23 C.F.R., 1947 Supp. 
the interests of the national security, the head of the department or agency concerned or his representative shall immediately suspend the employment of the person involved if he deems such suspension necessary in the interests of the national security and, following such investigation and review as he deems necessary, the head of the department or agency concerned shall terminate the employment of such suspended officer or employee whenever he shall determine such termination necessary or advisable in the interests of the national security, in accordance with the said act of August 26, 1950.

SEc. 7. Any person whose employment is suspended or terminated under the authority granted to heads of departments and agencies by or in accordance with the said act of August 26, 1950, or pursuant to the said Executive Order No. 9835 or any other security or loyalty program relating to officers or employees of the Government, shall not be reinstated or restored to duty or reemployed in the same department or agency and shall not be reemployed in any other department or agency, unless the head of the department or agency concerned finds that such reinstatement, restoration, or reemployment is clearly consistent with the interests of the national security, which finding shall be made a part of the records of such department or agency: Provided, that no person whose employment has been terminated under such authority thereafter may be employed by any other department or agency except after a determination by the Civil Service Commission that such person is eligible for such employment.

Sxc. 8. (a) The investigations conducted pursuant to this order shall be designed to develop information as to whether the employment or retention in employment in the Federal service of the person being investigated is clearly consistent with the interests of the national security. Such information shall relate, but shall not be limited, to the following:

(1) Depending on the relation of the Government employment to the national security:

(i) Any behavior, activities, or associations which tend to show that the individual is not reliable or trustworthy.

(ii) Any dehiberate misrepresentations, falsifications, or omissions of material facts.

(iii) Any criminal, infamous, dishonest, immoral, or notoriously disgraceful conduct, habitual use of intoxicants to excess, drug addiction, sexual perversion, or financial irresponsibility.

(iv) Any illness, including any mental condition, of a nature which in the opinion of competent medical authority may cause significant defect in the judgment or reliability of the employee, with due regard to the transient or continuing effect of the illness and the medical findings in such case.

(v) Any facts which furnish reason to believe that the individual may be subjected to coercion, influence, or pressure which may cause hin to act contrary to the best interests of the national security.

(2) Commission of any act of sabotage, espionage, treason, or sedition, or attempts thereat or preparation therefor, or conspiring with, or aiding or abetting, another to commit or attempt to commit any act of sabotage, espionage, treason, or sedition.

(3) Establishing or continuing a sympathetic association with a saboteur, spy, traitor, seditionist, anarchist, or revolutionist, or with an espionage or other secret agent or representative of a foreign nation, or any representative of a foreign nation whose iuterests may be inimical to the interests of the United States, or with any person who advocates the use of force or violence to overthrow the governnient of the Uuited States or the alteration of the form of government of the Uuited States by unconstitutional nieans.

(4) Advocacy of use of force or violence to overthrow the government of the United States, or of the alteration of the form of government of the United States by unconstitutional means.

(5) Membership in, or affiliation or sympathetic association with, any foreign or domestic organization, association, novement, group, or combination of persons which is totahtarian, Fascist, Communist, or subversive, or which has adopted, or shows, a policy of advocating or approving the commission of acts of force or violence to deny other persons their rights under the Constitution of the United States, or which seeks to alter the form of government of the United States by unconstitutional means.

(6) Intentional, unauthorized disclosure to any person of security information, or of other information disclosure of which is prohibited by law, or willful violation or disregard of security regulations.

(7) Performing or attempting to perform his duties, or otherwise acting, so as to serve the interests of another government in preference to the interests of the United States.

(b) The investigation of persons entering or einployed in the competitive service shall primarily be the responsibility of the Civil Service Commission, except in cases in which the head of a department or agency assumes that responsibility pursuant to law or by agreement 
with the Commission. The Commission shall furnish a full investigative report to the department or agency concerned.

(c) The investigation of persons (including consultants, however employed), entering employment of, or employed by, the Government other than in the competitive service shall primarily be the responsibility of the employing department or agency. Departments and agencies without investigative facilities may use the investigative facilities of the Civil Service Commission, and other departments and agencies may use such facilities under agreement with the Commission.

(d) There shall be referred promptly to the Federal Bureau of Investigation all investigations being conducted by any other agencies which develop information indicating that an individual may have been subjected to coercion, influence, or pressure to act contrary to the interests of the national security, or information relating to any of the matters described in subdivisions (2) through (8) of subsection (a) of this section. In cases so referred to it, the Federal Bureau of Investigation shall make a full field investigation.

(8) Refusal by the individual, upon the ground of constitutional privilege against selfincrimination, to testify before a congressional committee regarding charges of his alleged disloyalty or other misconduct.

SEC. 9. (a) There shall be established and maintained in the Civil Service Commission a security-investigations index covering all persons as to whom security investigations have been conducted by any department or agency of the Government under this order. The central index established and maintained by the Commission under Executive Order No. 9835 of March 21, 1947 , shall be made a part of the security-investigations index. The security-investigations index shall contain the names of each person investigated, adequate identifying information concerning each such person, and a reference to each department and agency which has conducted an investigation concerning the person involved or has suspended or terminated the employment of such person under the authority granted to heads of departments and agencies by or in accordance with the said act of August 26, 1950.

(b) The heads of all departments and agencies sball furnish promptly to the Civil Service Commission information appropriate for the establishment and maintenance of the securityinvestigations index.

(c) The reports and other investigative material and information developed by investigations conducted pursuant to any statute, order, or program described in section 7 of this order shall remain the property of the investigative agencies conducting the investigations, but may, subject to considerations of the national security, be retained by the department or agency concerned. Such reports and other investigative material and information shall be maintaincd in confidence, and no access shall be given thereto except, with the consent of the investigative agency concerned, to other departments and agencies conducting security programs under the authority granted by or in accordance with the said act of August 26, 1950, as may be required for the efficient conduct of Government busimess.

SEc. 10. Nothing in this order shall be construed as eliminating or modifying in any way the requirement for any investigation or any determination as to security which may be required by law.

SEc. 11. On' and after the effective date of this order the Loyalty Review Board established by Executive Order No. 9835 of March 21, 1947, shall not accept agency findings for review, upon appeal or otherwise. Appeals pending before the Loyalty Review Board on such date shall be heard to final determination in accordance with the provisions of the said Executive Order No. 9835, as amended. Agency determinations favorable to the officer or employee concerned pending before the Loyalty Review Board on such date shall be acted upon by such Board, and whenever the Board is not in agreement with such favorable determimation the case shall be remanded to the department or agency concerned for determination in accordance with the standards and procedures established pursuant to this order. Cases pending before the regional loyalty boards of the Civil Service Commission on which hearings bave not been initiated on such date shall be referred to the department or agency concerned. Cases being heard by regional loyalty boards on such date shall be heard to conclusion, and the determination of the board shall be forwarded to the head of the department or agency concerned: Provided, that if no specific department or agency is involved, the case shall be dismissed without prejudice to the apphicant. Investigations pending in the Federal Bureau of Investigation or the Civil Service Commission on such date shall be completed, and the reports thereon shall be made to the appropriate department or agency.

SEc. 12. Executive Order No. 9835 of March 21, 1947, as amended, is hereby revoked. For the purposes described in section 11 hereof the Loyalty Review Board and the regional loyalty 
boards of the Civil Service Commission shall continue to exist and function for a period of one hundred and twenty days from the effective date of this order, and the Department of Justice shall continue to furnish the information described in paragraph 3 of Part III of the said Executive Order No. 9835, but directly to the head of each department and agency.

SEc. 13. The Attorney General is requested to render to the heads of departments and agencies such advice as may be requisite to enable them to establish and maintain an appropriate employee-security program.

Sec. 14. (a) The Civil Service Commission, with the contimuing advice and collaboration of representatives of such departments and agencies as the National Security Council may designate, shall make a continuing study of the manner in which this order is being implemented by the departments and agencies of the Government for the purpose of determining:

(1) Deficiencies in the department and agency security programs established under this order which are inconsistent with the interests of, or directly or indirectly weaken, the national security.

(2) Tendencies in such programs to deny to individual employees fair, impartial, and equitable treatment at the hands of the Government, or rights under the Constitution and laws of the United States or this order.

Information affecting any department or agency developed or received during the course of such contimuing study shall be furnished immediately to the head of the department or agency concerned. The Civil Service Commission shall report to the National Security Council, at least semiannually, on the results of such study, shall recommeud means to correct any such deficiencies or tendencies, and shall inform the National Security Council immediately of any deficiency which is deemed to be of major importance.

(b) All departments and agencies of the Government are directed to cooperate with the Civil Service Commission to facilitate the accomplishment of the responsibilities assigned to it by subsection (a) of this section.

(c) To assist the Civil Service Commission in discharging its responsibilities under this order, the head of each department and agency shall, as soon as possible and in no event later than ninety days after receipt of the final investigative report on a civilian officer or employee subject to a full field investigation under the provisions of this order, advise the Commission as to the action taken with respect to such officer or employee. The information furnished by the heads of departinents and agencies pursuant to this section shall be included in the reports wbich the Civil Service Commission is required to submit to the National Security Council in accordance with subsection (a) of this section. Such reports shall set forth any deficiencies on the part of the heads of departments and agencies in taking timely action under this order, and shall mention specifically any instances of noncompliance with this subsection.

SEC. 15. This order shall become effective thirty days after the date hereof. 